\title{
EKSISTENSI RUANG TERBUKA PADA LINGKUNGAN PERMUKIMAN
}

\author{
Eva Elviana ${ }^{1}$, Diyan Lesmana ${ }^{2}$ \\ Progdi Arsitektur, Fakultas Arsitektur \& Desain, LPPM UPN “Veteran" Jawa Timur \\ 2. Progdi Arsitektur, Fakultas Arsitektur \& Desain, LPPM UPN “Veteran” Jawa Timur \\ Jl. Raya Rungkut Madya Gunung Anyar Surabaya 60293 \\ *Email: eva_elviana66@yahoo.com
}

\begin{abstract}
ABSTRAK
The housing environment that appears in many urban areas today, is available in the form of real estate and in the form of simple housing. The existence of these houses is equipped with supporting infrastructure. One of them is the availability of open space as a public facility, which can be utilized by all residents of housing. If you look at the historical aspects of past traditional settlements, such as the Tanean Lanjang Madura settlement, the Samin Bojonegoro Community Village, the Sumatra Karo Batak Village, and so on, it is found that there is open space as a public space. Where the function and role of open space are used for joint activities, gathering places and socializing, as well as the center of orientation of several groups of houses, so that the location tends to be in the center. The purpose of this study is to see the existence of open space of traditional settlements (past) and present. As well as analyzing the activities carried out by the pas community and its current development. By using the method of field observation (observation) and qualitative descriptive analysis, the results show that the existence of open space in the present, such as in residential or residential groups, still exists. If in the past traditional settlements, the existence of open spaces was used as a means to gather and socialize, then in its current development, open space could be used as a means of playing and exercising for children, recreational activities (gathering on holidays), supported economic activities (traders who sell), as well as a means of worship (Eid al-Fitr / Eid al-Adha). This shows the development and diversity of functions and activities in the open space, so that its utilization can increase economic values, religious values and other social values.
\end{abstract}

Keywords: Existence, Open Space, Past and Present.

\section{PENDAHULUAN}

Keberadaan ruang-ruang terbuka diantara bangunan perumahan atau permukiman dapat menciptakan keseimbangan lingkungan. Keseimbangan sebuah lingkungan, dapat dihasilkan dari komposisi solid-void (Trancik dalam Zahnd, 1999). Begitu pula pada sebuah kawasan perkotaan maupun lingkungan permukiman, banyak dijumpai adanya sebuah elemen solid yang bersifat massive, yang berasal dari massa bangunan/ gedung dan elemen void, yang berasal dari adanya ruang-ruang terbuka. Mengutip dari Mulyandari (2010), disebutkan bahwa keberadaan ruang-ruang terbuka ada yang berbentuk garis linier memanjang dan adapula yang berbentuk terpusat (square).

Ruang terbuka dengan bentuk memanjang, dapat berupa jalan, penghubung antar blok perumahan, jalur hijau pada median jalan, maupun tepi jalan, saluran terbuka, bahkan sungai dan jalur rel kereta api juga merupakan salah satu ruang terbuka dengan bentuk memanjang. Sedangkan ruang terbuka dengan bentuk memusat (square) adalah ruang terbuka, yang banyak dimanfaatkan sebagai taman, plaza, atau lapangan olah raga.

Keberadaan ruang terbuka pada kawasan perkotaan maupun lingkungan permukiman masa kini, mempunyai nilai yang sangat penting, jika ditinjau dari peran dan fungsinya. Ruang terbuka dengan bentuk memusat (square), berada pada posisi yang strategis, terletak di tengah kawasan permukiman. Sebagai tempat bertemu, berkumpul dan bersosialisasi antar warganya. Fungsi dan peran ini berkembang menyelaraskan kebutuhan, sehingga keberadaan ruang terbuka ini juga 
dapat dipakai sebagai sarana bersantai, bermain dan bersepeda bagi anak-anak, bagi yang dewasa digunakan sebagai sarana berkumpul dan bercengkerama terutama pada saat-saat hari senggang/ libur. Bahkan pada beberapa tempat, keberadaan ruang terbuka ini dimanfaatkan sebagai sarana untuk beribadah/

sholat bersama-sama pada hari Raya bagi umat Islam, serta berolah raga.

Dengan banyaknya orang berkumpul pada ruang terbuka, maka para pedagang makananpun akhirnya datang mendekat dan terjadilah transaksi jual beli. Dengan demikian keberadaan ruang terbuka ini secara tidak langsung adalah dapat meningkatkan nilai ekonomi masyarakat sekitarnya. Begitu pula pada saat peringatan hari Kemerdekaan, keberadaan ruang terbuka dimanfaatkan sebagai tempat penyelenggaraan lomba-lomba, bazar dan panggung hiburan. Sedangkan pada saat bulan Ramadhan, keberadaan ruang terbuka juga dipakai sebagai sarana berjualan makanan/ takjil. Pada beberapa tempat pula, keberadaan ruang terbuka ini juga dipakai untuk berkumpul dan berdoa bersama (istighosah).

Dengan banyaknya aktifitas yang dapat dilakukan pada ruang terbuka, maka ruang ini mempunyai peran dan fungsi yang sangat penting, guna mendukung aktifitas masyarakat dan meningkatkan kualitas hidup warganya.

Jika melihat pada beberapa permukiman arsitektur tradisional pada masa lalu keberadaan ruang terbuka ini juga berfungsi sebagai pengikat antar beberapa kelompok rumah. Seperti contohnya pada permukiman masyarakat Samin di Bojonegoro, rumah-rumah saling berhadapan berorientasi pada ruang terbuka yang ada di depannya dengan bentuk memanjang (Gambar 1). Ruang terbuka dimanfaatkan sebagai tempat berkumpul bagi masyarakatnya, dan pada saat panen tiba, dimanfaatkan sebagai ruang untuk menjemur padi atau daun tembakau (Ariani, 2010).

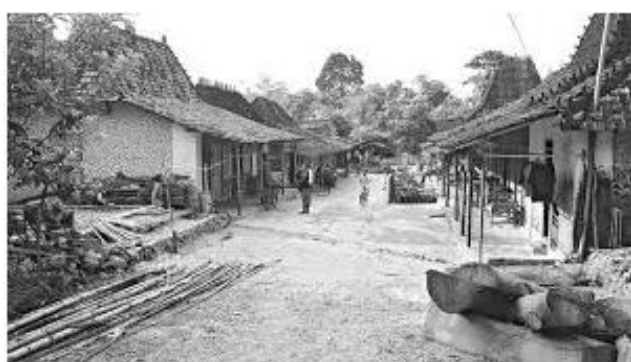

Gambar 1. Pola Permukiman Masyarakat Samin di Bojonegoro
Pada pola permukiman tradisional Tanean Lanjeng di Madura terdapat ruang terbuka (tanah/tanean) di bagian tengah yang berbentuk memanjang (lanjeng). Tanean adalah pusat kegiatan dari masyarakat Madura, karenanya banyak kegiatan yang bisa dilakukan disini, seperti menjemur padi, jagung dan hasil panen lainnya bahkan menjemur burung (Gambar 2). Selama menjemur hasil bumi, masyarakat Madura duduk-duduk di langgar sambil bercanda tawa dengan keluarga lainnya, hal ini dapat menambah keakraban antar keluarga (Ahsan, 2012).

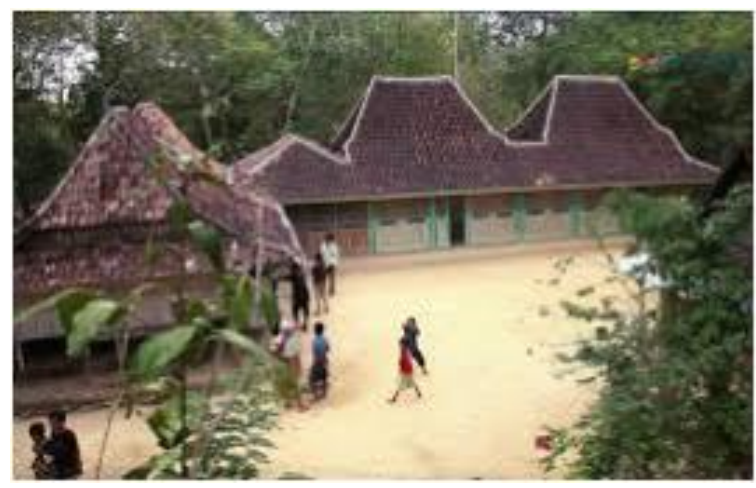

Gambar 2. Pola Permukiman Tanean Lanjeng Madura

Begitu pula pada beberapa permukiman tradisional lainnya, seperti permukiman Batak di Sumatera Utara, yang ditunjukkan pada gambar 3 , ruang terbuka yang terletak diantara deretan rumah tradisional, merupakan tempat berkumpulnya warga, untuk berkumpul dan bersosialisasi (Nuraini, 2004).

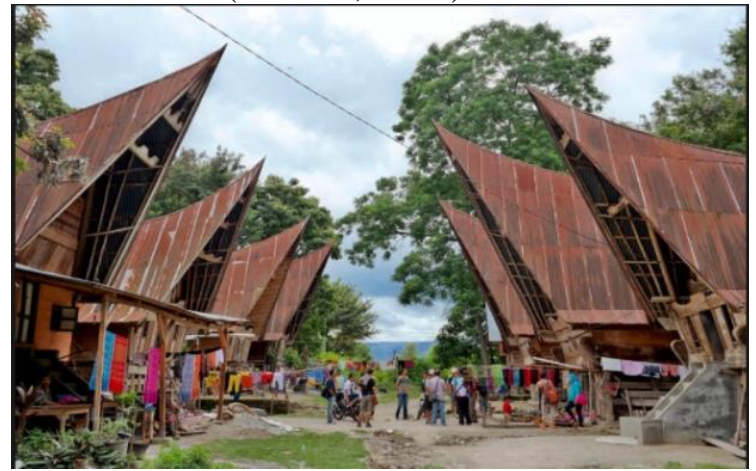

Gambar 3. Pola Permukiman Batak di Sumatera

Sedangkan gambar 4, menunjukkan adanya ruang terbuka diantara deretan memanjang rumah tradisional Tongkonan, yang berada di Sulawesi Selatan. Keberadaan ruang terbuka yang terletak di tengah area permukiman, menjadi pusat orientasi masyarakat dan sekaligus sebagai pusat tempat 
lenggarakannya upacara adat atau tradisi kebudayaan (Bigalke, 2016).

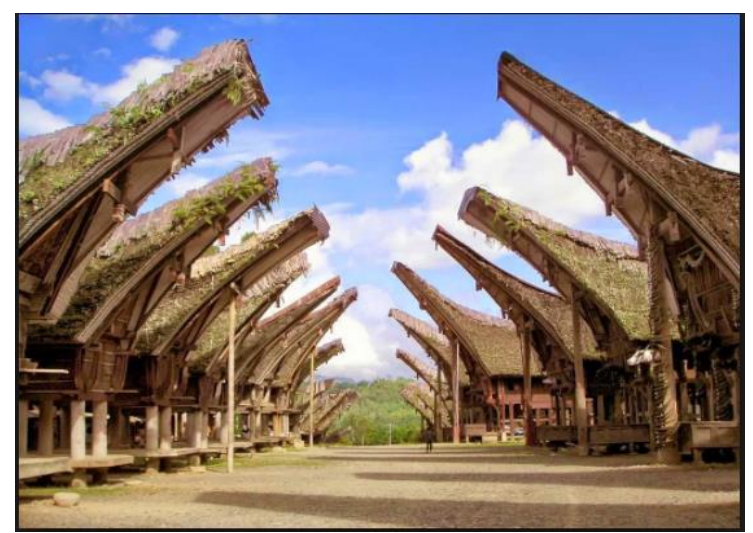

Gambar 4. Pola Permukiman Toraja di Sulawesi Selatan

Hal ini menunjukkan adanya dinamisasi kegiatan pada fungsi dan peran ruang terbuka. Aktifitas yang terselenggara pada ruang terbuka, dipengaruhi oleh karakter kegiatan masyarakat di lingkungan sekitarnya, tanpa mengurangi nilai dari peran dan fungsi ruang terbuka

\section{METODA PENELITIAN}

Untuk mempelajari pola peruntukan serta peran dan fungsi dari sebuah ruang terbuka pada permukiman modern saat ini, dilakukan dengan metode observation/ pengamatan lapangan dan interview.

Sedangkan untuk mempelajari pola peruntukan dan aktifitas pada ruang terbuka pada permukiman tradisional di masa lampau, menggunakan metode diachronic reading (Darjosanjoto, 2004), yakni melakukan pembacaan data-data bersumber dari referensi literatur/ kepustakaan.

Selanjutnya data dianalisa dengan menggunakan metode diskriptif kualitatif, (Faqih, 2007) untuk meninjau eksistensi peran dan fungsi ruang terbuka dari masa ke masa. Adanya pergeseran aktifitas, yang sangat khas, dipengaruhi oleh pola kegiatan dan karakter masyarakatnya.

\section{HASIL DAN PEMBAHASAN}

\section{Pola Keruangan dan Hirarki}

Jika mengamati pola ruang terbuka pada sebuah permukiman maupun perkampungan, tata letak dan bentuknya hampir mempunyai kemiripan. Berada pada lokasi yang strategis, di tengah area permukiman sehingga menjadi pusat orientasi, sehingga mempunyai hirarki yang sangat penting, bagi warga penghuni perumahan.

sama halnya dengan keberadaan Alun-alun pada sebuah kota.

Ruang Terbuka pada beberapa permukiman tradisional, mempunyai kemiripan, yakni berbentuk memusat (square), diikuti dengan pola tata letak rumah, yang berorientasi menghadap ke arah ruang terbuka. Seperti yang ditunjukkan pada permukiman Samin di Bojonegoro (gambar 1), permukiman Tanean Lanjeng di Madura (gambar 2), permukiman Batak di Sumatera Utara (gambar 3) dan permukinan Toraja di Sulawesi Selatan (gambar 4).Hal ini menunjukkan bahwa keberadaan ruang terbuka sebagai pusat orientasi, mempunyai hirarki yang sangat penting.

Demikian pula ruang terbuka pada permukiman kawasan perkotaan saat ini, dijumpai keberadaannya, dengan menempatkan pada lokasi yang strategis sehingga mudah diakses dari segala arah jalan perumahan.Tidak seluruh rumah berorientasi dan menghadap pada ruang terbuka, namun ruang terbuka dikelilingi oleh jalan pada sisi sisinya. Keberadaan ruang terbuka tidak hanya terpusat pada satu lokasi, namun menyebar, menyesuaikan dengan skala dan luas perumahannya.

Kondisi ruang terbuka di beberapa lingkungan perumahan sederhana di kawasan perkotaan, dapat dilihat pada gambar 5, yakni perumahan Dadapan Permai Sidoarjo, dan gambar 6, yakni perumahan Banjarsari Asri Gresik.

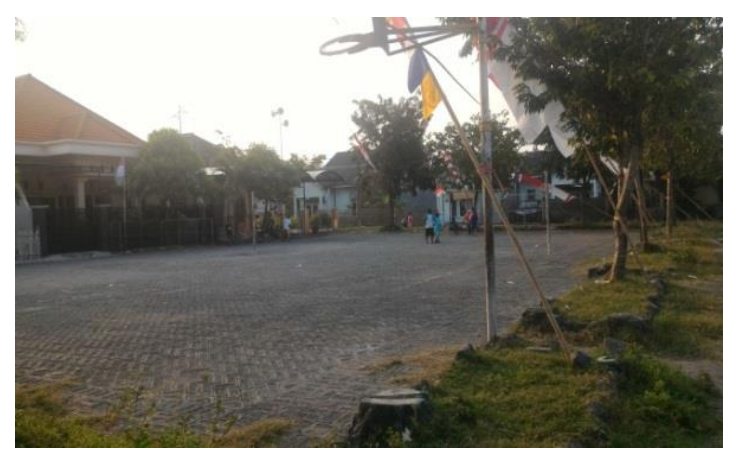

Gambar 5. Ruang Terbuka di Perumahan Sederhana Sidoarjo 


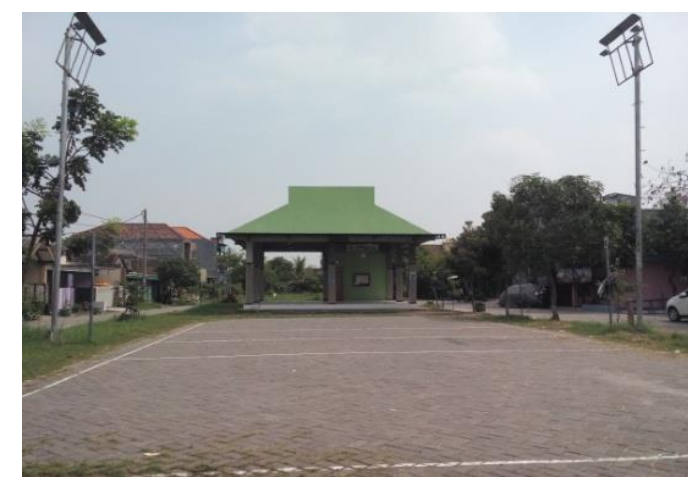

Gambar 6. Ruang Terbuka di Perumahan Sederhana Gresik

Untuk menggelar upacara adat, menari untuk menerima dan mengantar tamu, maupun memainkan beberapa atraksi kebudayaan lainnya (seperti pada permukiman Batak dan permukiman Toraja).

Sedangkan saat panen tiba, keberadaan ruang terbuka dipergunakan sebagai tempat untuk menjemur padi, tembakau, jagung dan hasil kebun lainnya, seperti pada permukiman Samin di Bojonegoro dan Tanean Lanjeng di Madura.

Sedangkan pada permukiman/ perumahan Sederhana masa kini, keberadaan ruang terbuka, tetap ada meski dengan ukuran yang tidak terlalu luas, namun mampu mendukung kebutuhan warga masyarakat di lingkungan perumahan. Dari hasil observasi yang dilakukan pada sebuah kawasan perumahan sederhana, di wilayah sub urban Sidoarjo dan Gresik, diperoleh hasil kegiatan yang dikakukan pada ruang terbuka seperti dalam tabel 1 berikut.

Tabel 1. Aktifitas Warga pada Ruang Terbuka

\begin{tabular}{|c|l|l|}
\hline No & \multicolumn{1}{|c|}{ Aktifitas } & Waktu Kegiata \\
\hline 1 & Lomba-lomba Agustusan & Pagi dan sore \\
\hline & Bazar Agustusan & Sore hari \\
\hline & Panggung Hiburan Agustusan & Malam hari \\
\hline & Malam Renungan Agustusan & Malam hari \\
\hline 2 & Doa Bersama (Istighozah) & Malam hari \\
\hline & Sholat Hari Raya Idul Fitri & Pagi hari \\
\hline & Sholat Hari raya Idul Adha & Pagi hari \\
\hline & Peringatan Maulud Nabi & Malam hari \\
\hline & $\begin{array}{l}\text { Tempat berjualan Takjil } \\
\text { Ramadhan }\end{array}$ & Sore hari \\
\hline 3 & Perayaan Sedeqah Bumi & Siang hari \\
\hline 4 & Senam bersama & Pagi hari \\
\hline & Olah.Raga futsal & Sore hari \\
\hline & Olah Raga Volley & Sore hari \\
\hline & Olah Raga Basket & Sore hari \\
\hline & Olah raga Badminton & Malam hari \\
\hline & Bersepeda bagi anak-anak & Sore hari \\
\hline
\end{tabular}

\begin{tabular}{|c|c|c|}
\hline No & $\begin{array}{r}\text { Aktifitas } \\
\end{array}$ & Waktu Kegiat: \\
\hline & Jalan sehat & Pagi hari \\
\hline & Lari Pagi/ Jogging & Pagi hari \\
\hline \multirow[t]{2}{*}{5} & Sarana Bermain Anak-anak & Sore hari \\
\hline & $\begin{array}{l}\text { Tempat Berkumpulnya } \\
\text { masyarakat pada waktu } \\
\text { senggang/ libur }\end{array}$ & Sore dan mala \\
\hline 6 & $\begin{array}{l}\text { Tempat berkumpulnya } \\
\text { pedagang/ pasar kaget }\end{array}$ & Pagi hari \\
\hline 7 & Tempat Penanaman TOGA & Pagi hari \\
\hline \multirow[t]{2}{*}{8} & $\begin{array}{l}\text { Tempat Kampanye Partai } \\
\text { Politik }\end{array}$ & Malam hari \\
\hline & $\begin{array}{l}\text { Tempat diselenggarakannya } \\
\text { Pemungutan Suara }\end{array}$ & Pagi hari \\
\hline \multirow[t]{2}{*}{9} & $\begin{array}{l}\text { Adanya Pasar Malam/ Pasar } \\
\text { Rakyat }\end{array}$ & Malam hari \\
\hline & Tempat Panggung Hiburan & Malam hari \\
\hline
\end{tabular}

\section{Fungsi Dan Peran Ruang Terbuka Dari Masa Ke Masa}

Jika melihat keberadaan ruang terbuka yang terletak diantara sekumpulan bangunanbangunan (rumah) arsitektur tradisional pada jaman dulu, maka perannya sangat penting sebagai pusat orientasi dan sekaligus sebagai tempat berkumpulnya masyarakat penghuni bangunan. Keberadaan ruang terbuka mempunyai makna dan filosofi tertentu sesuai dengan tata cara dan adat budayanya.

Aktifitas yang terselenggara pada ruang terbuka, lebih banyak merupakan aktifitas sosial, berkumpul dan bersenda gurau menikmati waktu senggang. Bahkan terkadang dimanfaatkan.

Dengan beragamnya aktifitas, tentunya tidak dapat diselenggarakan dalam satu waktu.Penggunaan waktu pemakaian diatur sedemikian rupa agar tidak bersamaan. Hal ini semakin menunjukkan eksistensi keberadaan ruang terbuka pada sebuah lingkungan perumahan sederhana di kota.

Pada ruang terbuka yang berada di kawasan permukiman elit/ mewah di perkotaan, agak sedikit berbeda karakter aktifitasnya. Yakni ruang terbuka lebih banyak dimanfaatkan sebagai taman atau plaza, dengan menggunakan "tema-tema" tertentu, dilengkapi dengan aneka pohon dan tanaman bunga, bangku taman dan lampu taman, patung/ sculpture, kolam air, serta jalur pedestrian untuk pejalan kaki. Sehingga fungsinya lebih pasif karena hanya dinikmati sebagai taman kota. 


\section{KESIMPULAN}

Kehadiran sebuah ruang terbuka, dari waktu ke waktu, dalam sebuah lingkungan permukiman tradisional (masa lalu) atau perumahan (masa kini) masih selalu ada, dengan bentuk dan ukuran yang berbeda-beda. Jika pada permukiman tradisional, terdapat fungsi dan peran yang sarat dengan makna maupun filosofi yang terkandung didalamnya, serta dipengaruhi oleh tradisi/ adat istiadat dan budaya masyarakatnya. Sedangkan pada masa kini, sudah berkembang fungsi dan perannya, namun makna filosofis sebagai pusat orientasi dan tempat berkumpul masih tetap adanya.

Keberadaan ruang terbuka pada lingkungan perumahan masa kini di kawasan perkotaan, ada yang berada pada perumahan sederhana serta ada yang berada pada perumahan mewah. Hal ini membawa ciri dan karakter kegiatan yang berbeda pula. Jika pada perumahan mewah sangat dipengaruhi oleh kemampuan pengembang/ developer, namun pada perumahan sederhana, akan tumbuh dan berkembang sesuai dengan kemampuan msyarakat penghuni perumahan. Namun keterbatasan kemampuan ini justru menimbulkan aktifitas beragam yang dapat ditampung pada ruang terbuka. Hal ini semakin menunjukkan eksistensi fungsi dan peran ruang terbuka, bahwa keberadaannya mampu menyesuaikan dengan karakter masyarakatnya.

Mengutip dari Mirsa (2012), bahwa peran dan fungsi ruang terbuka menjadi penting, karena secara fisik tidak hanya memberikan estetika visual bagi lingkungannya, namun juga dapat memberikan ciri/ menjadi penanda identitas lingkungan (identity of place).

\section{UCAPAN TERIMA KASIH}

Ungkapan terima kasih penulis sampaikan kepada LPPM, UPN "Veteran" Jawa Timur, yang telah memberi kesempatan kepada penulis untuk melakukan beberapa penelitian, khususnya yang berorientasi pada Permukiman Sederhana di Kawasan Perkotaan.
Ucapan terima kasih pula, penulis sempaikan kepada jajaran dekanat Fakultas Arsitektur dan Desain, rekan dosen dan mahasiswa di lingkungan Program Studi Arsitektur. Semoga dari penelitian ini dapat bermanfaat untuk perkembangan ilmu pengetahuan khususnya dibidang Arsitektur.

\section{Daftar Pustaka}

Ariani, dkk (2010) Masyarakat Samin di Bojonegor. Jakarta: Kemendikbud.

Bigalke, Terance (2016) Sejarah Sosial Tanah Toraja. Yogyakarta: Ombak.

Darjosanjoto, Endang (2004) Penelitian Arsitektur di Bidang Perumahan dan Permukiman. Surabaya: ITS Press.

Elviana, Eva (2017) Konsep Perancangan Ruang Terbuka Di Lingkungan Perumahan Sederhana Berbasis Partisipasi Masyarakat. Surabaya, LPPM UPN “Veteran” Jawa Timur.

Faqih, Muhammad( 2007) Kertas Kerja Kuliah Metodologi Penelitian Arsitektur. Surabaya, Pascasarjana Arsitektur, ITS

Mirsa, Rinaldi (2012) Elemen Tata Ruang Kota. Yogyakarta: Graha Ilmu.

Mudjiono, Zein (1986) Arsitektur Tradisional Madura. Surabaya, Laboratorium Arsitektur Tradisional FTSP ITS.

Mulyandari, Hestin (2011) Pengantar Arsitektur Kota. Yogyakarta: Andi Offset.

Nochian, Ashkan, et all (2015) A Comprehensive Public Open Space Categorization Using Classification System For Sustainable Development Of Public Open Spaces. Alam Cipta, International Journal of Sustainable Tropical Design Research and Practice, University Putra Malaysia

Nuraini, Cut (2004) Permukiman Suku Batak Mandailing. Yogyakarta: UGM Press.

Zahnd, Markus (1999) Perancangan Kota Secara Terpadu: Yogyakarta, Kanisius. 